\title{
The European social Union and EU legislative politics
}

Martinsen, Dorte Sindbjerg

Published in:

A European social union after the crisis

Publication date:

2017

Document version

Peer reviewed version

Citation for published version (APA):

Martinsen, D. S. (2017). The European social Union and EU legislative politics. In F. Vandenbroucke, C.

Barnard, \& G. de Baere (Eds.), A European social union after the crisis (pp. 459-476). Cambridge University Press. 


\title{
The European Social Union and EU legislative politics DORTE SINDBJERG MARTINSEN
}

\author{
Published in "A European social union after the crisis" Frank \\ Vandenbroucke; Cathrine Barnard; Geert de Baere (eds.). \\ Cambridge University Press, 2017. \\ pp. 459-476.
}

\section{Introduction}

The process of integration towards a European Social Union consists of both past achievements and current deficits. It has developed on a delicate balance between on the one hand constitutive community principles of free movement and non-discrimination and on the other hand Member State jealously guarding their welfare competences. Despite national concerns, EU social integration has occurred. Primary and secondary social legislation has been adopted through the years, building up a Community social dimension with coordination of social security across borders, equal pay and treatment between gender, health and safety at the work place, employment law, regulation regarding insolvency, the posting of workers, the social dialogue, etcetera. In addition, the open methods of coordination address a wider range of social issues, however, without being binding on the Member States. On the other hand, European integration challenges social protection. The more recent economic governance of the European Union constrains national welfare policies. Convergence criteria, the stability and growth pact, and the European semester strain contemporary social and fiscal policies in the Member States. The crises and austerity measures work severely against social policies both at the European and national level as various contributions in this volume demonstrate.

The current movement towards a European Social Union thus consists of fragmented and contradictory dynamics, which on balance have negative implications for welfare policies. Such implications may be severe indeed. Ferrera compares nowadays socioeconomic challenges with the ones faced 100 years ago, where local social communities were dissolved and replaced by national 
standards. Ferrera argues that it's the same kind of economic fusion we see today, and it requires pan-European responses in order to prevent social conflicts.

As was the case one hundred years ago at the domestic level, the Europeanization ('fusion') of national markets through freedom of movement and competition rules is (already has been) a tremendous trigger for growth and job creation in the EU's economy, enhancing life chances and welfare for European citizens. But it is also a source of social and spatial disruptions. Again economic 'fusion' requires the introduction of some common social standards, rights and obligations through a socially friendly institutional re-articulation of the novel Europeanised space of interaction. ${ }^{1}$

Such a social space of interaction appears to have a long way to go. The Juncker Commission has admitted to a certain need for social initiatives in the midst of crises, but it remains unclear where sufficient political entrepreneurship should come from. Vandenbroucke notes in his contribution to this volume that a European Social Union needs instruments. ${ }^{2}$ It needs supranational devices and common standards. A Social Union cannot come into being or address the full scope of European social challenges by means of soft law, recommendation or a flexible European semester. It needs binding measures and it needs politics. ${ }^{3}$

This Chapter examines the legislative politics of a Union social policy. It traces its development over time and its political mandate. The Chapter first examines how binding EU social policies have developed over time. It thus examines the evolvement of the regulatory field as well as by which institutions the devices were decided (Section 2). Secondly, the chapter turns to the more substantive side of EU social regulation, the content and main achievements of the EU social dimension (Section 3) and takes us up to current challenges and increased politicization of EU social integration (Sections 4 and 5). Thirdly, in order to capture the legislative politics and conflict lines of social Europe in a post-Lisbon setting, the decision-making process on the regulation of posted workers is analysed (Section 6). Finally, the chapter concludes that the recent adoption of an enforcement directive for the posting of workers demonstrates that EU legislative politics can still deliver binding measures - even in the difficult political setting of EU28 (Section 7). At the same

\footnotetext{
${ }^{1}$ M. Ferrera, 'Modest Beginnings, Timid Progresses: What's Next for Social Europe?', in B. Cantillon, H. Verschueren and P. Ploscar (eds.), Social Inclusion and Social Protection in the EU: Interactions between Law and Policy (Intersentia Publishing), p. 18.

${ }^{2}$ F. Vandenbroucke, 'The Idea of a European Social Union: why we need it and what it means', in this volume.

${ }^{3}$ F. Vandenbroucke, n2 above.
} 
time, however, political conflict lines of a European Social Union are clearly marked and nonmajoritarian decisions affects the legitimacy of decisions taken.

\section{The Development of EU Legislative Policies}

To adopt binding EU social measures is a difficult task. Institutionally the decision-making process is framed by the three legislative institutions of the European Union; the European Commission, the Council and the European Parliament (EP). The European Commission has the monopoly to propose legislation. Furthermore, it decides on Commission regulations and delegated acts. Internally, different Directorates Generals (DGs) may disagree on the aims of community policies as may the Commissioners. The Commissioner for internal market is unlikely to agree fully with the Commissioner for employment and social affairs on what should be the exact balance between internal market principles and social protection. The policy positions thus have to be coordinated internally in the Commission, which often times involves conflicts and compromises. ${ }^{4}$ In the Council of the European Union sits the Member States. The Member States have to agree, unanimously or by qualified majority. Now counting 28 governments with different ideological positions and socioeconomic legacies, establishing a qualified majority certainly faces many obstacles. The EP may be co-legislator in the decision-making process. The EP has to establish a majority between its 751 members and different political groups. Its internal dynamics are conditioned by which committee and which rapporteur are in charge of a dossier. Finally when colegislating, the Council and the EP has to establish a compromise between them.

There are thus reasons to assume that the EU legislative process is hindered by institutional and political rivalry and that only few pieces of secondary legislation within EU social policy are adopted. When examining the development of social policy secondary legislation between 1971 and up to the time of writing May 2016, we find that 234 directives and regulations have been adopted. ${ }^{5}$

\footnotetext{
${ }^{4}$ M. Hartlapp, J. Metz, and C. Rauh, Which Policy for Europe?: Power and Conflict inside the European Commission (Oxford University Press, 2014).

5 The time period was set 1971-2016 in order to begin from the year where one of the main piece of EU social regulation was adopted, namely Regulation (EEC) no. 1408/71 of the Council of 14 June 1971 on the application of social security schemes to employed persons and their families moving within the Community. The examination was carried out by means of EUR-LEX data base on consolidated legislation with the following search code; Consolidated legislation; directory of European Union consolidated legislation; 05 Freedom of movement for workers and social policy; 05.20 social policy; number of acts. Both legislation in force and not in force were included. As noted on the webpage of EUR-LEX consolidated legislation, the database is still in an 'experimental phase' and some references may be missing. However, a compilation of social policy legislation over time gives us an insights into the evolvement and type of regulatory instruments.
} 


\section{Figure 1.1: The development of EU social policy regulations and directives 1971-2016}

Author's compilation. Source: EUR-LEX directory on consolidated legislation, incl. legislation in force and not in force

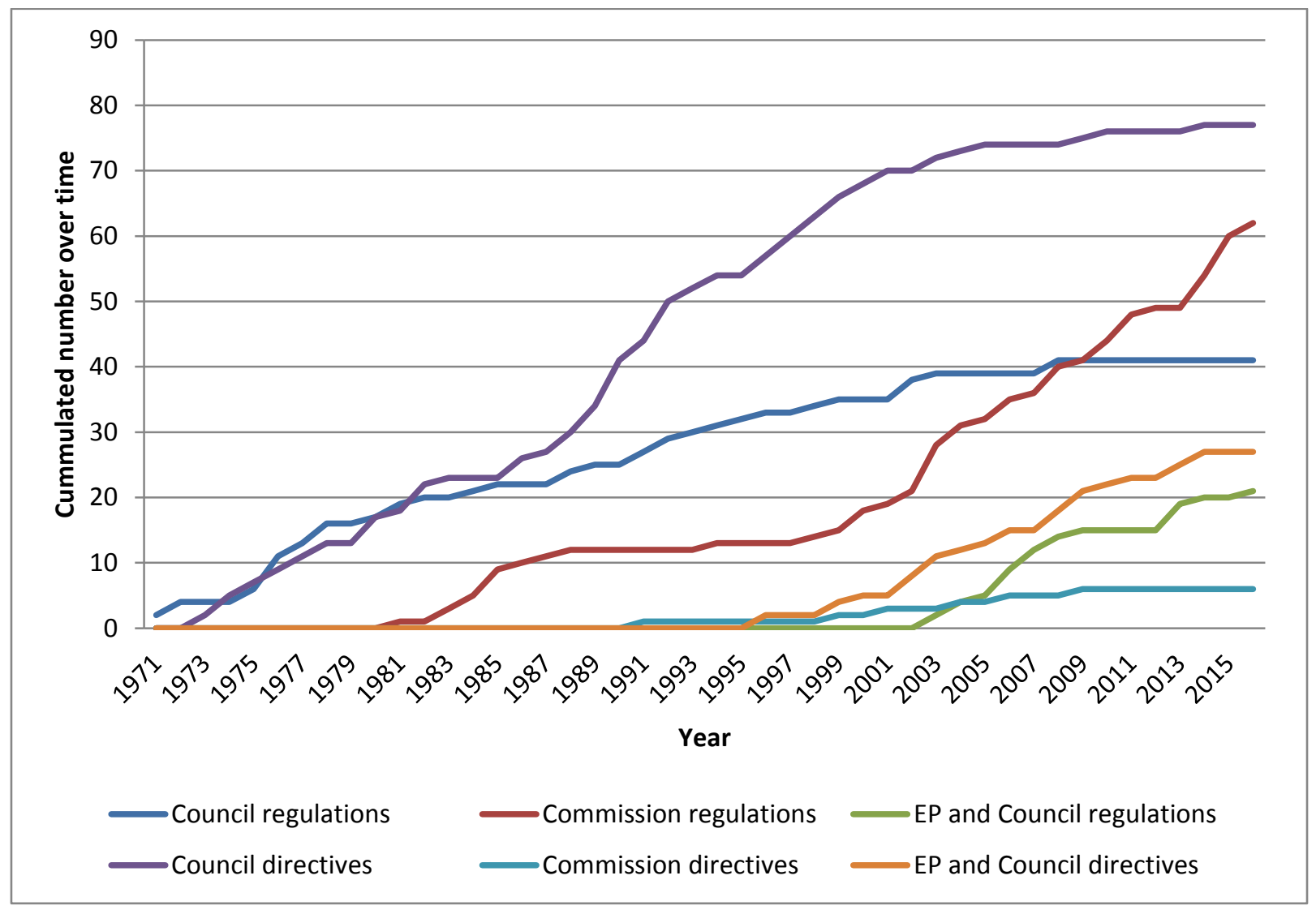

Figure 1.1 presents the accumulated adoption of EU social policy regulations and directives for an extensive time period. ${ }^{6}$ The type of regulatory act was manually sorted out for each year of adoption which contain important information. We see that the main type of regulatory act over time are Council directives, second Commission regulations and third Council regulations. Compared hereto regulations and directives adopted by the Council and the EP are modest.

The examination over time, may surprise the reader for two reasons. First, the Commission has a considerable importance as decision-maker. The amount of regulations adopted by the non-

\footnotetext{
${ }^{6}$ Regulations and directives are the two main binding legal acts in EU decision-making. A regulation shall be applied in its entirety across the EU and is directly binding, i.e. it does not have to be implemented by national law first. A directive sets outs the goals that the EU Member States must achieve, but the Member States have to adopt national legal instruments on how to reach these goals, i.e. the directive has to be implemented by national law first.
} 
majoritarian institution stands out. Second, although now a co-legislator in many areas, the role of the EP when it comes to the adoption of secondary legislation is still modest.

\section{A European Social Union - Achievements and Challenges}

However, Figure 1.1 also demonstrates that the EU legislative institutions produce binding, and thus enforceable, social regulation and continue to do so over time. Although welfare policies are formally regarded national competence, the European Union has gradually institutionalised an advanced form of social regulation.

One of the first regulations of the European Community was Regulation no. 3 adopted in 1958, which granted migrant workers moving between the Member States the right to access the social security schemes of a hosting Member State and export already earned social security rights. In 1971, the original regulation was reformed into Regulation 1408/71. ${ }^{7}$ In 2004, Regulation 1408/71 became Regulation 883/2004 ${ }^{8}$, which covers not only workers and self-employed individuals but all EU citizens and their family members. Also in the early days of European integration, Regulation $1612 / 68^{9}$ was adopted, granting migrant workers the right to the social advantages of a hosting Member State. Both Regulations constitute major interventions in the organizing principles of the welfare states, which have traditionally been based on demarcating principles of territoriality, residence and/or national citizenship. ${ }^{10}$ In essence they build up a system of transnational solidarity where Member States are obliged to protect one another's citizens against social risks if they come to work and reside. Rights are, however, subject to certain conditions which have continuously been negotiated and interpreted by the European institutions and within the Member States. Important here is the Residence Directive 2004/38 which sets out the link

\footnotetext{
${ }^{7}$ Regulation $1408 / 71$, n5 above.

${ }^{8}$ Regulation (EC) 883/2004 of the European Parliament and of the Council of 29 April 2004 on the coordination of social security systems.

${ }^{9}$ Now Regulation (EU) 492/2011 of the European Parliament and of the Council of 5 April 2011 on freedom of movement for workers within the Union.

${ }^{10}$ R. Cornelissen, 'The principle of territoriality and the Community Regulations on social security (Regulations 1408/71 and 574/72)' (1996) 33 Common Market Law Review 439; R. Cornelissen, '25 Years of Regulation (EEC) No. 1408/71. Its Achievements and its Limits.', in Swedish National Social Insurance Board (ed.), 25 Years of Regulation (EEC) No. 1408/71 for Migrant Workers - Past Experiences, Present Problems and Future Perspectives (Swedish National Social Insurance Board); A. Christensen and M. Malmstedt, 'Lex Loci Laboris versus Lex Loci Domicilii-An Inquiry into the Normative Foundations of European Social Security Law' (2000) 2 European Journal of Social Security 69; D.S. Martinsen, 'The Europeanization of Welfare - The Domestic Impact of Intra- European Social Security' (2005) 43 Journal of Common Market Studies 1027.
} 
between the right to reside and access to welfare benefits for the European migrant. ${ }^{11}$ The directive lays down that one has the right to reside as long as one is not an 'unreasonable burden' on the social system of a hosting Member State. ${ }^{12}$ However, the Directive does not define 'unreasonable burden'. As noted by Thym, the EU legislature is likely to have deliberately left the specific 'unreasonable burden' provision open and ambiguous as to allow for discrepancy. ${ }^{13}$

Setting the personal scope of a European Social Union, we can identify an expansive phase in EU politics, running approximately from the introduction of Union citizenship with the Maastricht Treaty in 1993 and peaking with the 2004 adoption of the Residence Directive and Regulation 883/2004 and the grand enlargement of that year. Shortly after, new political tunes sound increasingly loud. The no votes in France and the Netherlands to the constitutional Treaty expressed public concerns with the service directive's social impact, personalised as the 'Polish plumber' and the political campaigns 'the resurgence of nationalist and welfare chauvinist sentiments'. ${ }^{14}$ A free movement-welfare cleavage between old and new Member States has become increasingly expressed, with political positions against 'welfare tourism' expressed in EU-15, viewed in the new Member States as 'irrational', 'short-sighted' and protectionist. ${ }^{15}$ The situation came to a peak just before summer 2016 when the UK decided to leave the EU and thus cast the European Community into its most severe crisis ever. Free movement of persons and the right to cross border welfare were debated fiercely in the UK, and have been pointed out as a main reason for why the UK voted to leave. ${ }^{16}$ The scope and limits of social Europe has become high politics. The course of legal integration suggests a similar turn from an expansive reading of Union citizenship to a more restrictive approach. Dougan finds that between 1998-2008, the course of legal integration extended the application of Union citizenship on the basis of Treaty. ${ }^{17}$ With the Sala case in $1998^{18}$, the Court initiated a judicial vision of Union citizenship as a fundamental status

\footnotetext{
${ }^{11}$ Directive 2004/38/EC of the European Parliament and of the Council of 29 April 2004 on the right of citizens of the Union and their family members to move and reside freely within the territory of the Member States.

${ }^{12}$ As stated in the Directive's article 7 (1) b and article 14 (1).

${ }^{13}$ D. Thym, 'The elusive limits of solidarity: Residence rights of and social benefits for economically inactive Union citizens' (2015) 52 Common Market Law Review 17, p. 26.

${ }^{14}$ A. Hemerijck, Changing Welfare States (Oxford University Press, 2013), p. 320.

${ }^{15}$ D.S. Martinsen, and H. Vollaard, Implementing Social Europe in Times of Crises: Re-established Boundaries of Welfare?' (2014) 37 West European Politics 677.

16 V.J. Reenen, 'The aftermath of the Brexit vote - the verdict from a derided expert' (2016) available at: http://blogs.lse.ac.uk/politicsandpolicy/the-aftermath-of-the-brexit-vote-a-verdict-from-those-of-those-experts-werenot-supposed-to-listen-to/ [12 October 2016].

${ }^{17}$ M. Dougan, 'The Bubble that Burst: Exploring the Legitimacy of the Case Law on the Free Movement of Union Citizens' in M. Adams, H. de Waele, J. Meeusen and G. Straetmans (eds.) Judging Europes's Judges. The Legitimacy of the Case Law of the European Court of Justice (Hart, 2013).

${ }^{18}$ ECJ, judgment of 12 May 1998 in María Martínez Sala v Freistaat Bayern, C-85/96, ECLI:EU:C:1998:217.
} 
of Member State nationals. ${ }^{19}$ The vision was further developed and extended in the Grzelczyk ${ }^{20}$ and Baumbast $^{21}$ cases among others, granting Union citizens' rights of residence and equal treatment, as well as access to the welfare schemes of a hosting Member State, despite being economically inactive. In these cases the Court emphasised the fundamental status of Union citizenship as laid down in the primary law of the Treaty; 'a citizen of the Union enjoy a right of residence by direct application of Article 18(1) EC' ${ }^{22}$ From 2008 onwards the Court has, however, embarked on a more restrictive course. In the Förster ${ }^{23}$ and Vatsouras $^{24}$ cases, the Court examines the more restrictive formulations of secondary law, as contained in Directive 2004/38, derogating from Union citizens' general right to equal treatment. ${ }^{25}$ The more restrictive judicial approach has become even more notable in the recent caselaw of Dano, Alimanovic and García-Nieto. ${ }^{26}$ In the Dano case, the Court apparently took further note of political concerns, when ruling that an economically inactive citizen like Ms Dano was not entitled to equal treatment, did not have the right to non-contributory cash benefits under German law and did not have a right to reside under Directive 2004/38. The Alimanovic case follows the same line. Here, the Court ruled that jobcentre Neukölnn was right in terminating the imbursement of social assistance to Ms Alimanovic and her daughter after six months unemployment. It is striking that here the Court based its restrictive reading of the right to equal treatment on secondary law, whereas the fundamental status of Union citizenship as stated in primary law recedes into the background. Also the later case García-Nieto and others continues the restrictive interpretation of EU citizens' access to social assistance despite being family members of an EU worker, hereby adding 'another dimension to the realization that the heyday of a justicedriven EU social citizenship is behind us'. ${ }^{27}$

\footnotetext{
${ }^{19}$ Dougan, n17 above, at p. 133.

${ }^{20}$ ECJ, judgment of 20 September 2001 in Rudy Grzelczyk v Centre public d'aide sociale d'Ottignies-Louvain-la-Neuve, C-184/99, ECLI:EU:C:2001:458.

${ }^{21}$ ECJ, judgment of 17 September 2002 in Baumbast and $R v$ Secretary of State for the Home Department, C-413/99, ECLI:EU:C:2002:493.

${ }^{22}$ See Advocate-General, conclusion of 5 July 2001 in Baumbast and R v Secretary of State for the Home Department, C-413/99, ECLI:EU:C:2001:385.

${ }^{23}$ ECJ, judgment of 18 November 2008 in Jacqueline Förster v Hoofddirectie van de Informatie Beheer Groep, C158/07, ECLI:EU:C:2008:630.

${ }^{24}$ ECJ, judgment of 4 June 2009 in Athanasios Vatsouras $v$ Arbeitsgemeinschaft (ARGE), C-22/08, ECLI:EU:C:2009:344.

${ }^{25}$ Dougan, 17 above, at p. 140.

${ }^{26}$ ECJ judgments of 11 November 2014 in Elisabeta Dano and Florin Dano v Jobcenter Leipzig, C- 333/13, ECLI:EU:C:2014:2358; of 26 March 2015 in Jobcenter Berlin Neukölln v Nazifa Alimanovic and Others, C-67/14, ECLI:EU:C:2015:210; and of 25 February in Vestische Arbeit Jobcenter Kreis Recklinghausen v Jovanna García-Nieto and Others, C-299/14, ECLI:EU:C:2016:114.

${ }^{27}$ D. Kramer, 'Short-term Residence, Social Benefits and the Family; an Analysis of Case C-299/14 (García-Nieto and others)' (2016) available at: http://europeanlawblog.eu/?p=3120 [12 October 2016].
} 
A more restrictive phase in political and judicial terms is thus identifiable in the evolvement of a European Social Union and its core features, meaning the free movement of persons, the right to cross-border welfare and equal treatment. ${ }^{28}$ The Court and the Commission have proven rather responsive to public and political concerns, former visions for European citizenship have been shaken and rights have become more complex and differentiated. At the same time, EU politics has moved 'permissive consensus' to 'constraining dissensus'. ${ }^{29}$ Specifically, as notable from public opinion, politicization of EU citizens' rights to welfare in a hosting Member State has been on the rise. $^{30}$

\section{Legislating Posting of Workers ${ }^{31}$}

Regulating posting of workers has historically been and still is a politically conflictual part of social Europe. As cross-border welfare, regulating posting of workers intersects the internal market and social policy. The politics of regulating workers posted in another Member State dates back to the 1980s when the relation between public procurement regulation and the internal market was first debated. ${ }^{32}$ The trade unions in the construction sector demanded a social clause in the public procurement regulations. The unions wanted the clause to be in line with the ILO Convention 94, meaning that posting firms would comply with the working conditions and collective agreements of hosting countries. But at that time, the Council was not ready to adopt a mandatory social clause.

The European Commission had, however, noted the concerns of the construction sector and in its 1991 social action programme, it stated that it would propose a separate directive on the posting of workers. ${ }^{33}$ In the social action programme, the Commission also stated that it would

\footnotetext{
${ }^{28}$ See Dougan, n17 above; E. Spaventa, 'Earned citizenship - understanding Union citizenship through its scope', in D. Kochenov (ed.), EU Citizenship and Federalism: the Role of Rights (Cambridge University Press, 2015); N.N. Shuibhne, 'Limits rising, duties ascending: The changing legal shape of Union citizenship' (2015) 52 Common Market Law Review 889; and H. Verschueren, 'Preventing 'benefit tourism' in the EU: A narrow or broad interpretation of the possibilities offered by the ECJ in Dano?' (2015) 52 Common Market Law Review 363.

${ }^{29}$ L. Hooghe, and G. Marks, 'A postfunctionalist theory of European integration: From permissive consensus to constraining dissensus' (2009) 39 British Journal of Political Science 1.

${ }^{30}$ D.S. Martinsen, and J.S. Thierry, 'Implementing Union Solidarity in the Nordic Welfare State', contribution to the panel 'Social Policy: Still an Area of National Sovereignty?', Trento SGEU Conference 15-18 June 2016 (on file with the author).

${ }^{31}$ The empirics of this section is based on chapter 6 of D.S. Martinsen, An Ever More Powerful Court? The Political Constraints of Legal Integration in the European Union (Oxford University Press, 2015).

${ }^{32}$ J. Cremers, J.E. Dølvik, and G. Bosch, 'Posting of Workers in the Single Market: Attempts to Prevent Social Dumping and Regime Competition in the EU' (2007) 38 Industrial Relations Journal 6.

${ }^{33}$ E. Kolehmainen, 'The Directive concerning the posting of workers: synchronization of the functions of national legal systems' (1998) 20 Comparative Labour Law and Policy Journal 71; Martinsen, n32 above.
} 
propose a principle of chain liability to guard the social rights of posted workers in subcontracting. In its proposal for the posting of workers directive, chain liability was, however, taken out. ${ }^{34}$ Apparently, the Commission assessed back then that a principle of chain liability was not feasible.

The Commission's proposal was negotiated for no less than five years and marked by deep conflicts internally in the Council but also between Council members and the Commission. Fierce disagreements were thus notable between internal market and social preferences, between posting and hosting Member States, between EU regulation and national law and practices and along more ideological lines between left and right. In addition posting of workers regulation has been marked by fierce political reactions against the judicial interpretations of the ECJ and the EU legislature.

When the original posting of workers directive was negotiated, the Rush Portuguesa case ${ }^{35}$ from 1990 was a crucial reference point. Back then the Court had concluded that Community law did not preclude Member States from applying national labour law or collective agreements onto posting firms. Hosting Member States thus used the case as a justification for enacting national labour law onto posted workers. ${ }^{36}$ The Commission took a different position, aiming to modify the impact of the case-law, which the Commission found to work against the internal market principles.

In its original proposal, the Commission proposed an article 3.2 according to which workers posted for less than three months, would be subject to the home Member State's labour laws. ${ }^{37}$ Political negotiations came to centre on the scope of Article 3. The EP was until 1993 only involved through the cooperation procedure. With the Maastricht Treaty it, however, gained co-legislator status. However, the EP still influenced early negotiations. The EP argued that the three months period where home Member State's legislation should be applicable was unacceptable in social terms and should be reduced to one month. The Commission accepted this view and presented a new proposal June $1993^{38}$, reducing the period to one month. ${ }^{39}$

The new proposal was, however, not welcomed by the majority of Council's members. In the finally adopted version, the period of which home Member State's legislation would be applicable was reduced from one month to eight days. Furthermore, in particular Finland, Germany,

\footnotetext{
${ }^{34} \mathrm{COM}(91) 230$ Proposal for a Council Directive concerning the posting of workers in the framework of the provision of services (Brussels, 1 August 1991).

35 ECJ, judgment of 27 March 1990 in Rush Portuguesa Ld ${ }^{a}$ v Office national d'immigration, C-113/89, ECLI:EU:C:1990:142.

${ }^{36}$ P. Davies, 'The Posted Workers Directive and the EC Treaty' (2002) 31 Industrial Law Journal 98, p. 300.

${ }^{37}$ See article 3.2 of the original proposal COM(91)230, n34 above, at p. 22.

${ }^{38} \mathrm{COM}(93) 225$, Amended proposal for a Council Directive concerning the posting of workers in the framework of the provision of services (Brussels, 15 June 1993).

${ }^{39}$ Martinsen, n32 above, at p. 192.
} 
Austria, Luxembourg and France pushed for a wider application of the host country's national labour laws or their collective agreements. ${ }^{40}$ This led to a fundamental change of the Directive's Article 3. Article 3(1) established which laws of the host Member State should be applied to posted workers, particularly those regarding minimum wages, working time, and paid annual leave. The Council majority added another 8 subparagraphs to the 3.1 and 3.2 originally part of the Commission's proposal. Article 3.1 came to set out the floor of protection - and the other subparagraphs added on. In particular article 3.7, 3.8 and 3.10 were important. Article 3.7 established that the floor of protection in Article 3.1 'shall not prevent application of terms and conditions of employment which are more favourable to workers'. Article 3.8 added that rights could also be derived from collective agreements' not only from legislation. Finally, Article 3.10 allowed the hosting Member State to take further measures in relation to posted workers than those laid down in article 3.1. Article 3.10 has been regarded as the article which made Article 3.1 an non-exhaustive, open list of measures. ${ }^{41}$

In December 1996, the posting of workers directive was adopted. ${ }^{42}$ As a result of a political battle between internal market principles and social protection, it can be argued that the adopted directive foremost focused on the latter. The directive can thus be regarded as a major achievement for social Europe, but one which relies much on justifying and protecting national schemes in an internal market.

A decade later, this agreement on where to strike the balance between internal market and national social protection was severely challenged by the ECJ.

\section{Legal Challenges and Political Responses}

Known as the 'Laval quartet', the famous four cases Viking, Laval, Rüffert, and Commission v Luxembourg were ruled between the late 1997 and the summer of $1998 .{ }^{43}$ In the cases, the European Court gave more consideration to the free movement principles against national labour regulation.

\footnotetext{
${ }^{40}$ See Kolehmainen, n33 above.

${ }^{41}$ Kolehmainen, n33 above, at p. 86.

${ }^{42}$ Directive 96/71/EC of the European Parliament and the Council of 16 December 1996 concerning the posting of workers in the framework of the provision of services [1996] OJ L 018.

${ }^{43}$ ECJ, judgments of 11 December 2007 in International Transport Workers' Federation and Finnish Seamen's Union $v$ Viking Line ABP and OÜ Viking Line Eesti, C-438/05, ECLI:EU:C:2007:772; of 18 December 2007 in Laval un Partneri Ltd v Svenska Byggnadsarbetareförbundet, Svenska Byggnadsarbetareförbundets avdelning 1, Byggettan and Svenska Elektrikerförbundet, C-341/05, ECLI:EU:C:2007:809; of 3 April 2008 in Dirk Rüffert v Land Niedersachsen, C-346/06, ECLI:EU:C:2008:189; and of 19 June 2008 in Commission of the European Communities v Grand Duchy of Luxemburg, C-319/06, ECLI:EU:C:2008:350.
} 
In the Viking case, the Court ruled that the right to strike can only be exercised within certain limits. In the Laval case, the Court followed suit and concluded that the Treaty's Article 49 (now Article 56 TFEU) and Article 3 of the posting of workers' directive meant that a trade union could not force a posting firm to sign a collective agreement more favourable than the minimum conditions set in the posting of workers directive. The Rüffert case laid down that the public procurement act in Lower Saxony was against Community law. And in the last case Commission v Luxembourg, the Commission found that Luxembourg had not transposed Articles 3.1 and 3.10 of the posting of workers directive correctly, having imposed too many national standards on posting firms. The Court had its own view on Article 3.10, laying down that since the article constituted a derogation from principle of freedom to provide services, it had to be interpreted in a strict manner, which Luxembourg had not. ${ }^{44}$

The Laval quartet thus tipped the balance towards the internal market. Political responses, however, came forcefully and from different institutions. First, the European Trade Union Confederation (ETUC) and national trade unions responded with fierce criticism. ETUC proclaimed that the Court 'had confirmed a hierarchy of norms, with market freedoms highest in the hierarchy and the fundamental rights of collective bargaining and action in second place'. The European social partners wanted the European legislators to respond by unambiguously clarify that economic freedoms must respect fundamental social rights.

Secondly, the EP took a strong position against the rulings and became a leading force in demanding political action. When Jose Manuel Barroso ran for his second term as President of the European Commission, the left wing of the EP demanded that in order to support him, he should promise to propose a revision of the posting of workers' directive and bring a solution to the 'case

\footnotetext{
${ }^{44}$ For a more detailed examination of the cases, see for example, A.C.L. Davies, 'One Step Forward, Two Steps Back? The Viking and Laval Cases in the ECJ' (2008) 37 Industrial Law Journal 126; C. Kilpatrick, 'Laval's regulatory conundrum: collective standard-setting and the Court's new approach to posted workers' (2009) 34 European Law Review 844; C. Joerges, and F. Rödl, 'Informal Politics, Formalised Law and the 'Social Deficit' of European Integration: Reflections after the Judgements of the ECJ in Viking and Laval' (2009) 15 European Law Journal 1; J. Malmberg, 'The Impact of the ECJ Judgements on Viking, Laval, Rüffert and Luxembourg on the Practice of Collective Bargaining and the Effectiveness of Social Action' (2010) Directorate General for Internal Policies study, PE 440.275; M. Blauberger, 'With Luxembourg in mind... the remaking of national policies in the face of ECJ jurisprudence' (2012) 19 Journal of European Public Policy 109; C. Barnard, 'EU Employment Law and the European Social Model: The Past, the Present and the Future' (2014) 67 Current Legal Problems 199; D. Seikel, 'Class struggle in the shadow of Luxembourg. The domestic impact of the European Court of Justice's case law on the regulation of working conditions' (2015) 22 Journal of European Public Policy 1166.
} 
law problem'. In September 2009, standing before the EP, Barroso thus committed himself to deliver on the case law problem. ${ }^{45}$

\section{Legislative politics in a post-Lisbon setting}

Despite the declared commitment from the Commission's president, it took another 2.5 years for the Commission to present its new proposals. It proved difficult to form a common position internally in the Commission. Due to the salience of the issue, the college of Commissioners' was involved, as was the President. Furthermore, DG Internal Market, Industry, Entrepreneurship and SMEs and DG Employment, Social Affairs and Inclusion disagreed on the content of the proposal. Also the European social partners tried to influence the agenda-setting of the proposal. ${ }^{46}$

On 21 March 2012, the Commission was, however, finally ready to present two documents: (1) a proposal for the so called Monti II Regulation ${ }^{47}$, and (2) a proposal for an enforcement directive on the posting of workers ${ }^{48}$.

The Monti II proposal was a regulatory response to the Viking and Laval case law and aimed to clarify under which conditions the right to collective action could be exercised within the internal market. The proposal, however, proved to be short-lived. The Lisbon Treaty had empowered the national parliaments with an Early Warning Mechanism (EWM). ${ }^{49}$ The mechanism gives parliaments the competence to issue reasoned opinions within eight weeks after a new proposal has been presented by the Commission. If one-third of the national parliaments raise an objection against a proposal and reason this objection in the principle of subsidiarity, the Commission have to reconsider the proposal and decide whether to withdraw it, change it or maintain it.

Although the national parliaments have many times issued reasoned opinions, the Monti II proposal was the first time they managed to pass the one-third threshold and do so within the eight week deadline. It was thus the first time that the national parliaments threw the 'yellow card'.

\footnotetext{
45 European Parliament 'Minutes of the meeting of 14 June 2010' (2010) available at: http://www.europarl.europa.eu/RegData/organes/bureau/proces_verbal/2010/06-14/BUR_PV(2010)06-14_EN.pdf [13 October 2016]

${ }^{46}$ Martinsen, 32 above, at p. 200.

${ }^{47} \mathrm{COM}(2012) 130$ Proposal for a Council Regulation on the exercise of the right to take collective action within the context of the freedom of establishment and the freedom to provide services (Brussels, 23 March 2012), which is named after the former commissioner and former Italian prime minister Mario Monti.

${ }^{48}$ COM(2012)131 Proposal for a Directive of the European Parliament and of the Council on the enforcement of Directive 96/71/EC concerning the posting of workers in the framework of the provision of services (Brussels, 21 March 2012).

${ }^{49}$ For the EWM mechanism, see Article 12 of the Lisbon Treaty and the Protocol (no. 2) on the application of the principles of subsidiarity and proportionality, articles 6 and 7.
} 
Although the Commission did not officially agree that its proposal was in conflict with subsidiarity, it decided to withdraw its proposal on the 12 September 2012. Monti II was out of the picture.

The EU legislators were thus left with the proposal for an enforcement directive. Although it had been important for the Commission not to open up for a full revision of the posting of workers directive, the enforcement proposal proved to be conflictual. Especially two provisions in the proposal divided the Member States and the Members of the EP: Article 9 dealt with the list of national control measures that a host Member State can take to secure that a posting firm complies with national rules and agreements. The Commission here proposed a closed list of control measures. Article 12 put chain liability onto the Community negotiation table: the Commission proposed a principle, termed as 'joint and several liability'. According to this principle the main contractor would be responsible for the first subcontractor regarding the pay of minimum wages, social security contributions, and taxes. Joint liability should apply to the construction sector only.

Long and difficult negotiations followed. The Polish member of the European Peoples Party Danuta Jazlowiecka became EP rapporteur on the proposal. Her position was that Article 9 should be maintained as a closed list, but Article 12 should be deleted. Jazlowiecka's draft report was opposed to by the majority of the Employment and Social Affairs committee, which was responsible for the dossier and also faced considerable opposition within the EP as a whole. In particular, the Socialists \& Democrats (S\&D) group was against the rapporteur's approach, wanting an open list of control measures and binding rule of joint and several liability across sectors, meaning measures that are not limited to the construction sector.

Also in the Council of Ministers disagreements loomed large. A conflict line was drawn mainly between hosting and posting states. On one side, the majority of old Member States assumed the position of hosting Member States and defended their right to control posting companies. On the other side, the Eastern European Member States and the UK defended the internal market; favouring Article 9 as proposed by the Commission but opposing Article 12 on joint and several liability regardless of the sector.

Fierce negotiations were held within and between the EU legislators, crystallizing different views on the balance between economic freedoms and social protection. Up until the Council's Employment, Social Policy, Health and Consumer Affairs configuration meeting in October 2013, the emerging common position seemed to be a non-exhaustive list of control measures combined with either a voluntary principle or no principle of joint liability. However, in particular France kept 
insisting on a binding principle of joint liability, whereas Poland and the UK took a firm position against.

The special relationship formed between Poland and the UK was suddenly harmed. Late November 2013, Cameron came out with his featured article 'Free movement within Europe needs to be less free'. ${ }^{50}$ Although Cameron addressed social security for migrant workers and not posting of workers as such, Poland found the article inappropriate and it came to influence the negotiations on the posting of workers. Cameron's statements influenced Council decision making on the enforcement directive, and in this late stage of negotiations Poland shifted side over to France, away from the UK. France had convinced Poland of the importance to signal unity for a social Europe. ${ }^{51}$ With the Polish change of position, a compromise could be established in the Council and with the EP. On 15 May 2014 the Enforcement Directive of the posting of workers was adopted, with a nonexhaustive list of control measures and a binding principles of joint and several liability for the first subcontractor in the construction sector. ${ }^{52}$ The adopted Article 12 also lays down that chain responsibility may be adopted for all other sectors. An important exemption is however also part of the provision. If the contractor has shown due diligence as defined by national law, the Member State may decide not to hold the contractor liable.

The enforcement directive for the posting of workers is thus the latest legislative result within social Europe. The Juncker Commission has in its 2016 work programme promised new initiatives and the current President has launched a more social agenda, where posted workers should be ensured 'the same pay for the same job at the same place'. ${ }^{3}$ Thus the Commission announced a 'labour mobility package' was under way. However, key parts hereof have been paralysed by political developments. The revision of Regulation 883/2004 was postponed to after the British referendum on UK EU membership and still has not been presented. On 8 March 2016, the Commission presented a proposal for revising the posting of workers directive. ${ }^{54}$ However, , 13

\footnotetext{
${ }^{50}$ D. Cameron, 'Free movement within Europe needs to be less free', Financial Times, 26 November 2016, available at: https://www.ft.com/content/add36222-56be-11e3-ab12-00144feabdc0 [13 October 2013].

${ }^{51}$ Martinsen, $\mathrm{n} 32$ above, at p. 216.

52 Directive 2014/67/EU of the European Parliament and of the Council of 15 May 2014 on the enforcement of Directive 96/71/EC concerning the posting of workers in the framework of the provision of services and amending Regulation (EU) No 1024/2012 on administrative cooperation through the Internal Market Information System [2015] OJ L 159/11.

${ }^{53}$ Quoted in A. Eriksson 'Eastern EU states lose battle on workers' pay', EU Observer, 20 July 2016, available at: https://euobserver.com/economic/134433 [13 October 2016].

${ }^{54}$ COM(2016)128 Directive of the European Parliament and of the Council amending Directive 96/71/EC of The European Parliament and of the Council of 16 December 1996 concerning the posting of workers in the framework of the provision of services (Brussels 8 March 2016).
} 
parliamentary chambers ${ }^{55}$ submitted a reasoned opinion to the Commission, finding its proposal against the principle of subsidiarity. Together these reasoned opinions constituted another yellow card for the Commission to consider. However, in contrast to the Monti II proposal, the Commission this time decided to maintain its proposal, which is currently under negotiations. The Commission insisted on the need to re-regulate posting of workers, and this time its proposal is clearer in its social content than the 2012 proposals. Also this time, the proposal is supported both by ETUC and the S\&D group of the EP. When explaining the decision to maintain the proposal despite the yellow card, the Social Affairs Commissioner Thyssen emphasised the need to 'build bridges' between EU workers and that the UK exit had taught the Commission the need to provide more social protection in the internal market in order to address many Europeans fear of globalization. ${ }^{56}$ A more social turn in the Commission's position is thus noted. It remains to be seen how a compromise can be established between hosting and sending Member States in the Council as well as with the EP.

\section{Conclusion}

The European Union has over time developed a social side to it in a delicate balance between internal market and social protection, between supranational and national competences. In setting the de facto scope and limits of social Europe, legislative politics play a key role. First because it has the capacity to adopt binding measures, which the Member States are obliged to implement and the European Union can enforce. Secondly, because they are the venue through which political agreements can be adopted by the EU majoritarian institutions. This is crucial when we consider the legitimacy of a European Social Union. Building up a European Social Union not only needs supranational devices ${ }^{57}$, it also needs a political mandate to ensure legitimacy.

The social implications of the internal market and the economic governance of the European Union stands out - also to the voters. EU social regulations is increasingly politicised. As demonstrated by the case of posting of workers regulation, also EU legislative politics has its clear conflict lines. However, when looking at the development of EU social legislation over time it

\footnotetext{
${ }^{55}$ A reasoned opinion was submitted by: Bulgaria National Assembly, the Czech Republic Chamber of Deputies and the Senate, Denmark Folketinget, Estonia Riigikogu, Croatia Hrvatski sabor, Hungary National Assembly, Lithuania Saeima, Letland Seimas, Poland Sejm and Senate, Rumania Chamber of Deputies and Senate.

${ }^{56}$ Quoted in Eriksson, n53 above.

${ }^{57}$ Vandenbroucke, n2 above.
} 
becomes clear that most decisions are taken without the EP. Also the European Commission has a decisive regulatory role.

As other contributions to this volume have pointed out, the major decisions on the scope and limits of a European Social Union are not taken by means of the classic community method and its majoritarian institutions. This fact calls a set of fundamental challenges and asymmetries to the fore, which constitute considerable obstacles not only to a European Social Union - but also to the European Union itself:

(1) Decisions are sometimes taken by non-majoritarian institutions, by the few, by the experts. A European Social Union cannot emerge out of Brussels talking to Brussels. It cannot be imposed by a technocratic logic. The European Central Bank has appeared on the scene with a major say on national welfare policies. At the same time the European parliament and the national parliaments are not involved in main decisions taken, but as the posting of workers case demonstrates they will make noise where they can if not included.

(2) As a result of decisions taken by the few, we see a process sometimes remote from the electorates but at the same time the impact of decisions taken fall onto the many. In particular as a result of the new tools of economic governance, European integration has become even more asymmetric in that decisions are taken by the heads of states in the European Council and empower the European Commission to evaluate the fiscal policies of Member States ${ }^{58}$ but without ensuring parliamentary accountability through the national parliaments or the EP.

(3) What about the European Court then? Can it not be a driver of social rights? The European judiciary has been argued to be a successful driver of social rights, compensating for the inabilities of EU legislative politics. ${ }^{59}$ However, in recent judgements the Court has continued the restrictive interpretations of Union citizens right to cross border welfare, no longer referring to the fundamental status of Union citizenship as set out in the Treaty but instead to the more restrictive content of secondary legislation, meaning directive 2004/38. As the Chapter by Kornezov shows ${ }^{60}$, the Court lost the opportunity to apply the charter against the austerity measures. In addition, the Laval quartet was seen as a severe non-

\footnotetext{
${ }^{58}$ K. Anderson, Social Policy in the European Union (Palgrave Macmillan, 2015).

${ }^{59}$ J.A. Caporaso, and S. Tarrow, 'Polanyi in Brussels: Supranational Institutions and the Transnational Embedding of Markets' (2009) 63 International Organization 593.

${ }^{60}$ A. Kornezov, 'Social rights, the Charter and the ECHR - caveats, austerity and other disasters', in this volume.
} 
social move by stating internal market principles above national labour law. In addition, the Court is a non-majoritarian institution and as such it does not have democratic legitimacy as decision-maker. The ability of legislative politics to speak back to the Court and adjust secondary legislation in line with the political majority is therefore important from a democratic and legitimacy point of view.

To conclude, for a European Social Union to turn into reality it inarguably needs a political mandate and political ownership. It needs to progress in a politically accountable manner. It cannot happen without political voice - but if disregarding its need for a political mandate, political voice against it may come to sound increasingly loud. 